\title{
STUDIES ON SOME COMPLICATIONS OF LONG BONE FRACTURES REPAIRS IN DOGS
}

\section{Shaaban Gadallah", Mohamed Marzok " and Inas El-Husseiny "}

"Depart. of Surgery, Anaesthesiology and Radiology, Fac. of Vet. Med., Cairo University.

"- Depart. of Surgery, Anaesthesiology and Radiology, Fac. of Vet. Med., Kaferelsheikh University.

\begin{abstract}
Six hundred and thirty one dogs with long bone fractures were treated at the clinics faculty of Veterinary Medicine, Cairo and kafrelsheikh Universities, during the period from January 1998 to January 2009. Out of 631 cases 90 cases showed 273 different types of complications. These complications were classified into two main types: Those from improper management (47.6\%) which included fracture disease $(21 \%)$ and implant failure (26.6\%). While the other type of complications were referred to fracture healing (52.4\%) which included delayedunion (16.1\%), non-union (8.8\%), mal-union (6.2\%), hypertrophic callus (15.3\%) and osteomyelitis (6\%). The incidence of complications were studied and discussed in relation to the age, the weight of the animal, type \& state of fracture, concurrent soft tissue injuries, type of reduction and the method or methods of fixation. The recorded complication were assessed radio-graphically and some of them undergone to surgical management.

The obtained results showed that the incidence of complications was very high in humeral (29.3\%) and femoral (35.2\%) fractures particularly in young and senile ages, heavy weight dogs, long standing old fractures, compound comminuted fractures associated with severe concurrent soft tissue injuries and those fractures fixed via external cooptation or external skeletal fixation (ESF) and in some fractures fixed by internal fixation.
\end{abstract}


Treatment options gave satisfactory results in terms of rapid return to full limb function in some cases of slight malalignment, hypertropic callus, delayed union, joint stiffness with mild arthrosis and early stage of muscle atrophy. However unsatisfactory results were obtained in terms of severe lameness in case of long standing old fractures, joint stiffness with severe arthrosis, late stage of muscle atrophy, recurrent implant failure, non union and osteomyelitis.

The present study emphasized on the importance of the age, weight, type of fractured bone, type of fracture, state of fracture, concurrent soft tissue injuries, type of reduction and the method or methods of fixation. All these factors collectively should be taken in consideration during long bone fracture management. Otherwise if one of these factors is neglected single or multiple complications will take place.

\section{INTRODUCTION}

Bone fractures constitute a major problem in small animal practice particularly in dogs. The primary aim of fracture treatment is to restore the function of the injured limb as soon as possible with minimal complications (Aron, 1998 and Shahar, 2000). Various reconstructive methods have been adopted for management of different types of canine long bone fractures, including internal fixation with open reduction (Hulse, 1997 and Piermatti \& Gretchen, 1997), external skeletal fixation with open or closed reduction (Egger, 1998) and external cooptation (DeCamp, 1993). Selection of the method of fixation depends upon fracture configuration, the size and age of the animal, the number of limbs involved, concurrent soft tissue injuries and the familiarity of the surgeon with the equipment and techniques. These all factors are important to be taken in consideration to prevent complication after management of long bone fractures in canine patients (Aron, 1998). 
Complications may occur with each type of fracture fixation. Minor complications such as slight malalignment and hypertrophic callus are not so serious. On the other hand, major complications, including delayed union and non union, severe malalignment, osteomyelitis and implant failure are considered dangerous (Johnson et al, 1994, Miller et al, 1998 and Rabins, 1998).

The goal of the present study is to report the possible complications associated with long bone fracture repair in dogs with special reference to their radiographic assessment and surgical management.

\section{MATERIALS \& METHODS}

Six hundred and thirty one dogs of different sexes, breeds, ages and body weight with fractures of long bones of the limbs (humerus, radius /ulna, femur and tibia /fibula and metacarpal /metatarsal bones) were treated at the surgery clinics faculty of Veterinary Medicine, Cairo and Kafrelsheikh Universities during the period from January 1998 to January 2009. Out of 631 cases of treated fractures 90 cases showed different types of complications. The age, weight, type of fractured bone, type of fracture (closed versus open), type and location of fracture line, types of reduction, methods of fixation, state of fracture (fresh versus old) and concurrent soft tissue injuries were recorded and analyzed in all complicated cases. Each dog received standard diagnostic evaluations, including orthopaedic and radiographic examinations.

All dogs were treated according to the principles of AO/ASIF using open or closed reductions and different types of internal and or external skeletal fixations, or external coaptation. The method of fracture repair was selected depending on the fractures-patient assessment score (Hulse 
\& Johnson, 1999). Follow up information were obtained from the medical records, radiographs and personal communication with the owners. Owners were asked to describe the extent of functional recovery that was evident in the dog during and after fracture repair. The results of clinical and radiographical assessment were analyzed as described by (Gadallah et al, 2002). Complications of long bone fractures were classified into two types; complications due to improper management (fracture disease and implant failure) and those complications of fracture healing (delayed union, non-union mal-union, hypertrophic callus and osteormyelitis). Management of these complications was directed to avoid or correct some of them. These measures included preventive measures and surgical interventions.

\section{RESULTS}

The results showed that out of 631 cases (135 humerus, 125 radius \& ulna, 250 femur, 78 Tibia \& fibula and 43 metacarpal/ matatarsal fractures) of previously treated long bone fractures, 90 cases showed 273 complications of different types (table 1). The complications of improper management were 130 (57 fracture disease and the others 73 were implant failure). While the complications of fracture healing were 143 (44 delayed union, 24 non-union, 17 mal-union 42 hypertrophic callus and 16 osteomyelitis). The incidence of complications for each long bone were analyzed and illustrated in tables (2, 3, 4, 5 and 6). Moreover plate 1 to 6 showed the radiographic pictures of some recorded complications. The results of surgical management for each type of complication were also reported in (table 7), while plate (7) showed the ideal method for application of bone plates, intramedullary pinning and acrylic external skeletal fixation. 


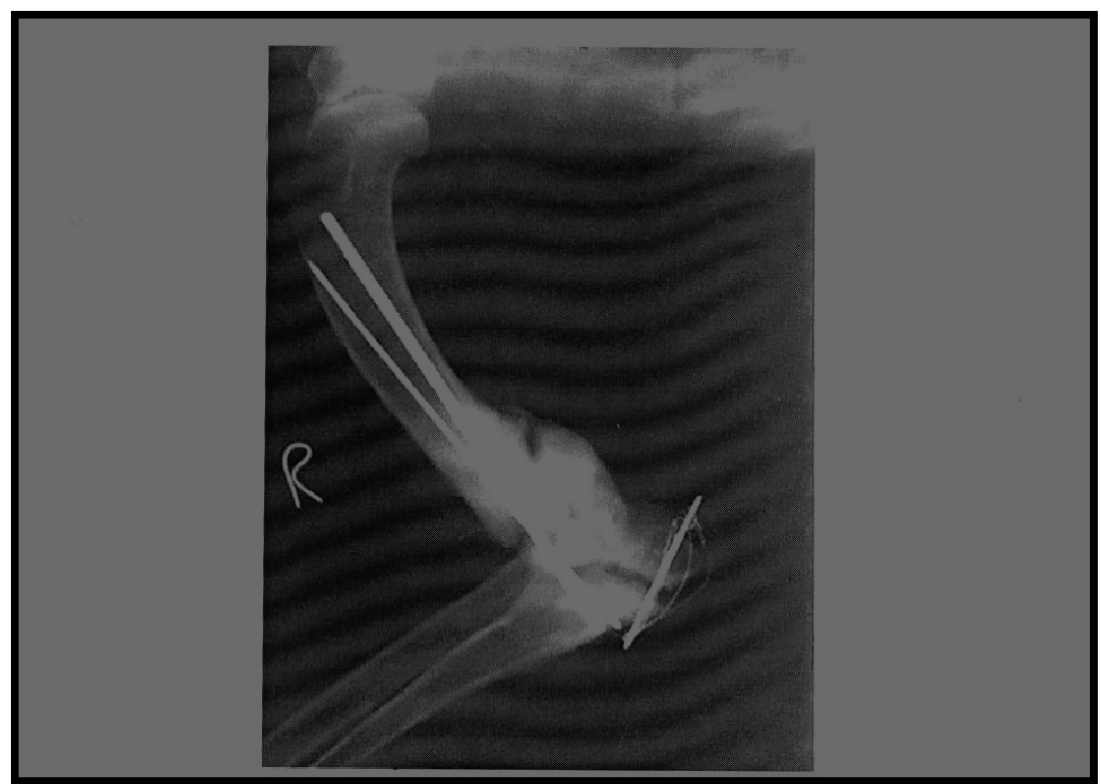

Plate (1): Distal humeral fracture fixed via multiple Steinman pins, lag screw and tension band wiring. Note severe arthrosis in the elbow joint.

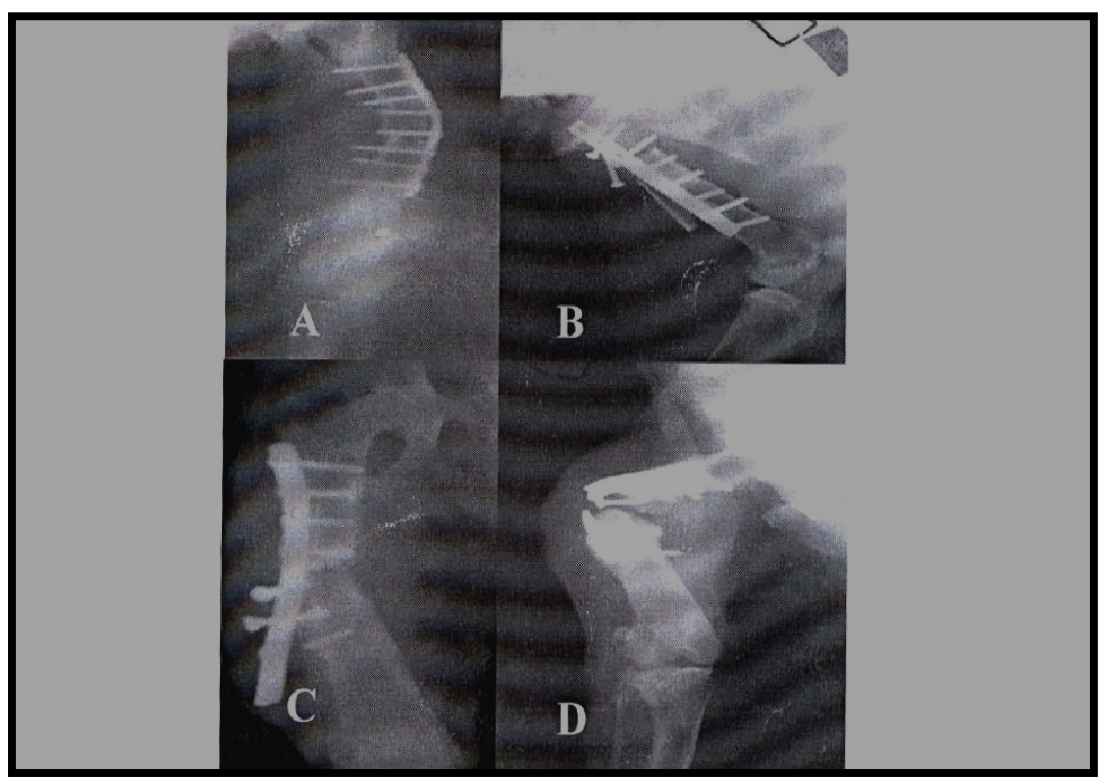

Plate (2): Implant failure as a result of bending (A),loosening (B) and breaking of the screws and the plate (C\&D). 


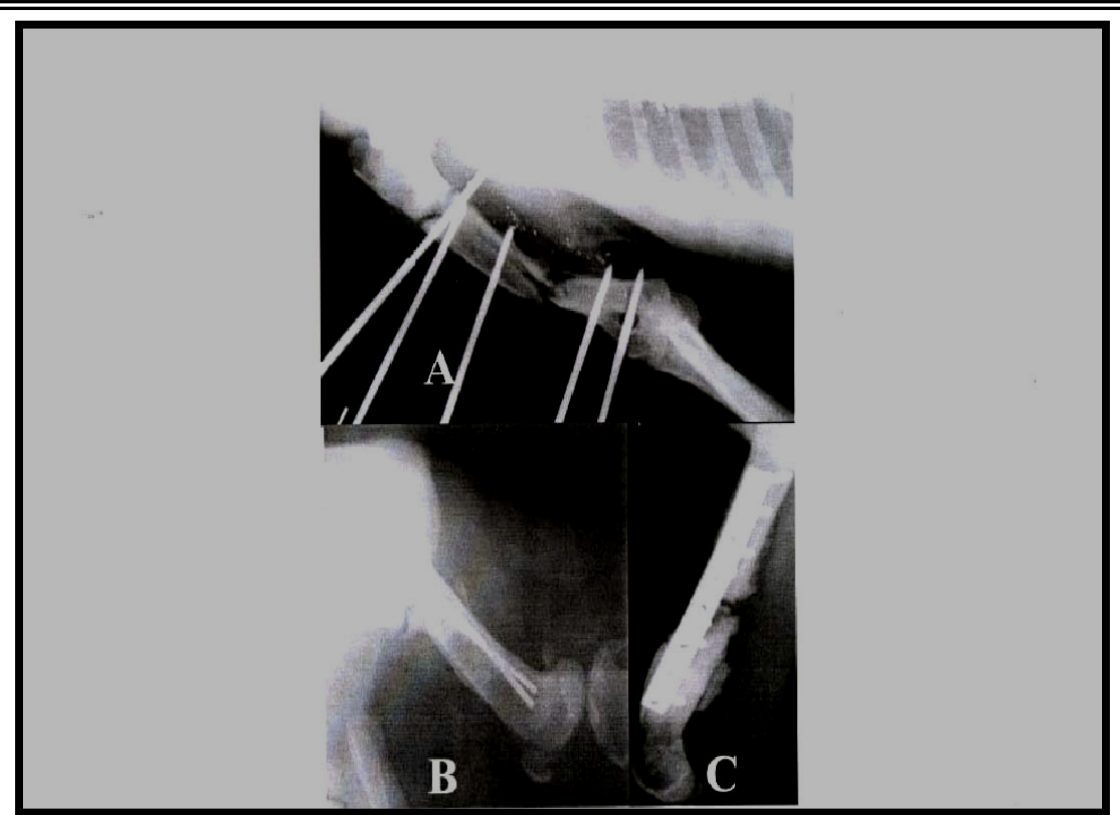

Plate (3): Delayed union and non-union in comminuted humeral fracture fixed via acrylic ESF (A), In femoral fracture fixed via multiple pins (elephant callus) (B) and in femoral fracture fixed by bone plate (C).

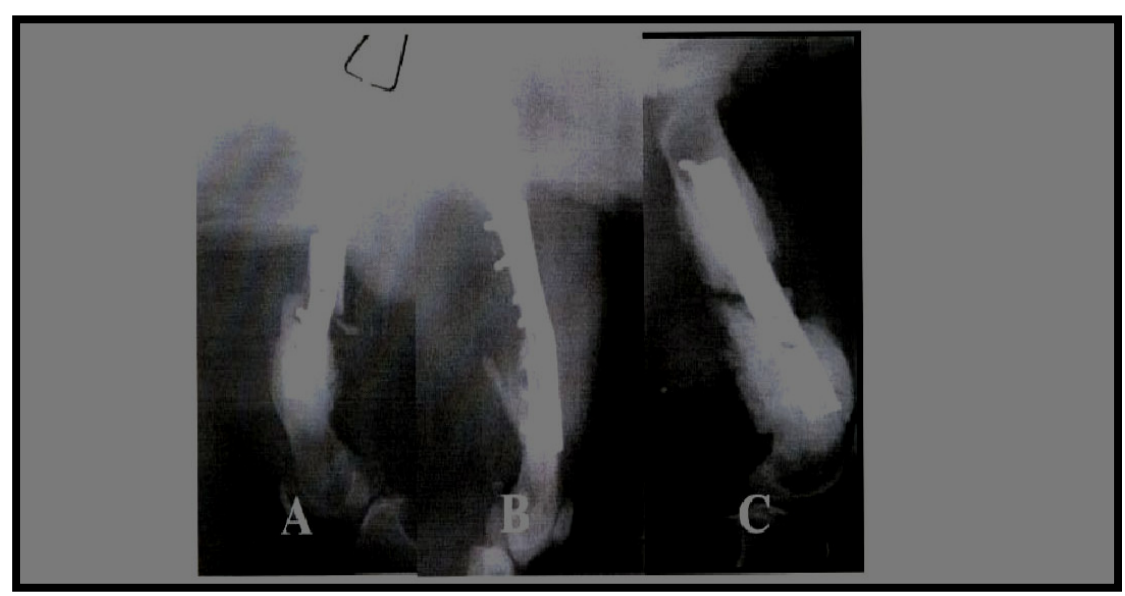

Plate (4): Hypertrophic callus. Non bridging callus observed as a result of instability at the fracture site (A), excessive periosteal stripping in immature dog (B) and osteomyelitis (C). 


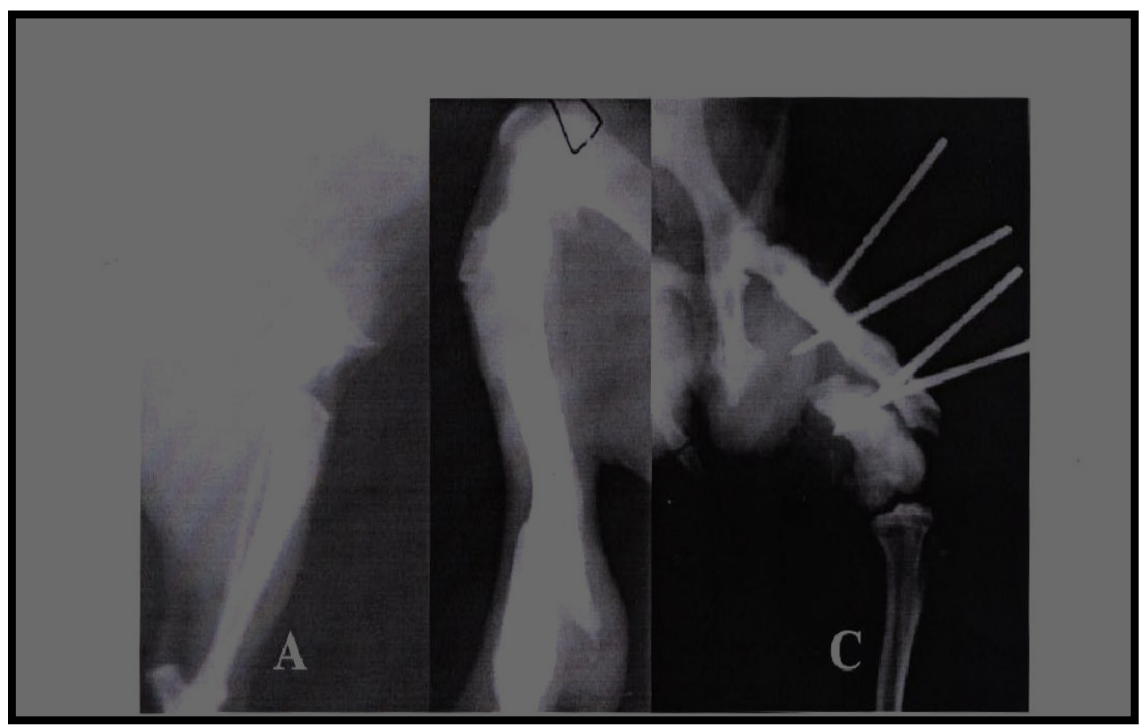

Plate (5): Mal-union in a neglected case of supraconylar femoral fracture (A), in a tibial fracture after removal of a crylic ESF (B) and in a femoral fracture fixed by $\operatorname{ESF}(\mathrm{C})$.

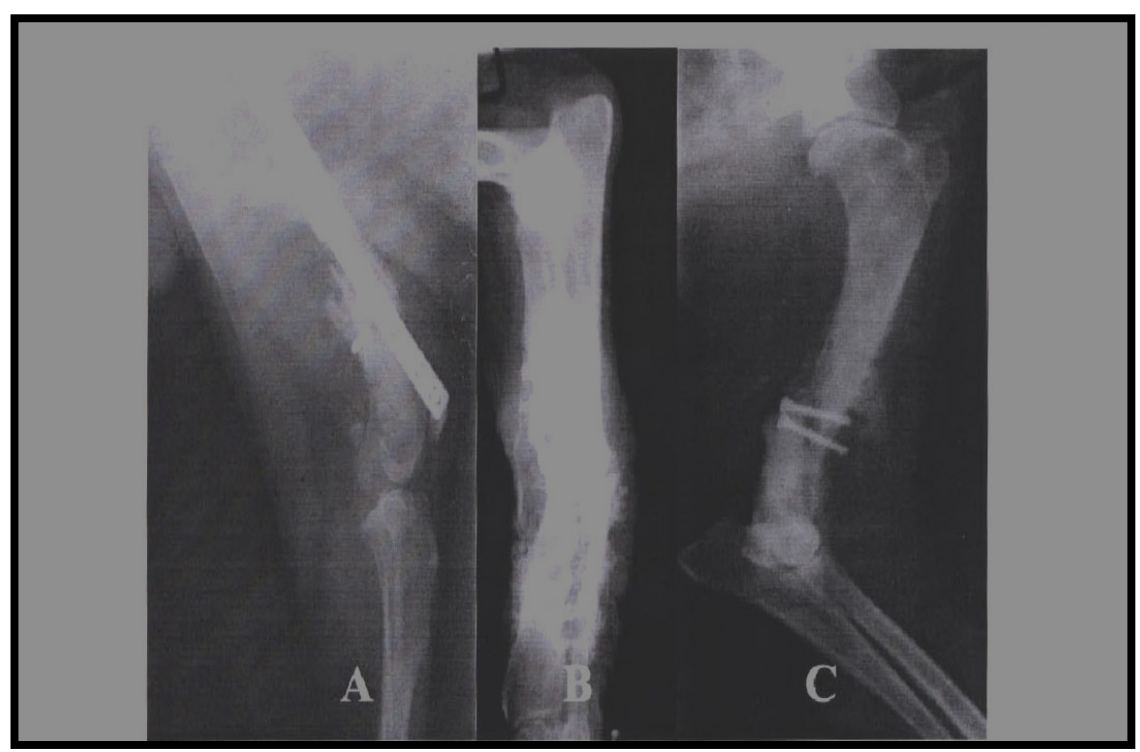

Plate (6): Osteomyelitis, in femoral fracture fixed by bone plate (A), in comminuted radial/ulnar fracture after removal of the implant (B)and in oblique humeral fracture fixed via lag screws. 


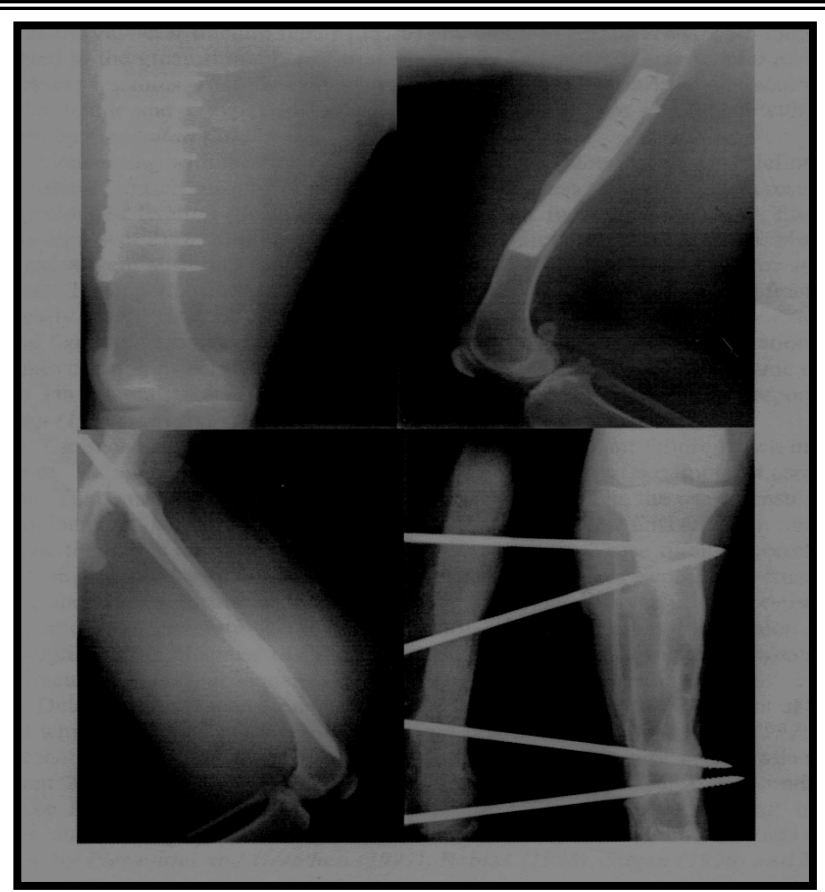

Plate (7): Showing the ideal method for application of the bone plate (A\& B), $\operatorname{IMP}(\mathrm{C})$ and ESF (D).

\section{DISCUSSION}

In the present study, complications of long bone fractures were classified into two types; complications due to improper management which included fracture disease (21\%) and implant failure (26.6\%). The second type of complications was resulting from fracture healing (52.4\%). These types of complications comprised delayed union (16.1\%), non union (8.8\%), malunion (6.2\%), hypertrophic callus (15.3\%) and osteomyelits (6\%). In this respect, Dvorak et al, (2000) classified long bone fracture complications into minor complications which are acceptable for the surgeon and the animal like hypertrophic callus and slight mal-alignment, while major complications, included delayed union and non- union, osteomyelitis and implant failure which are considered dangerous. 
The incidence of complications was very high in femoral and humeral fracture repair $(35.25 \%)$ and $(29.3 \%)$ respectively. This might be attributed to the greatest number of treated cases of femoral (250 cases) and humeral (125 cases) fractures. Also these types of bones had different varieties of fractures (8 types in femur and 6 types in humerus). These findings are consistent with that reported by Gadallah et al, (2002).

Concerning the first type of complications, fracture disease is defined as a syndrome of muscle atrophy or contracture, Joint stiffness and osteoperosis resulting from prolonged fixation (Johnson \& DeCamp, 1999). In the present study, fracture disease represent (21\%) from the total number of complications (57/273 case). Most of these cases were suffering muscle atrophy and joint stiffness due to mild or severe arthrosis. This phenomenon was commonly observed in old longstanding fractures and nearly in all cases of fractures fixed either by external cooptation or external skeletal fixation. Because the principals of external fixation depend upon fixation of a joint above and joint below the fracture site: Moreover it was observed in some cases treated via internal fixation for long period of time. This agrees with the reports of DeCamp, (1993), Egger (1998) and Oakley (1999).

The second important type of complications was implant failure which means failure of fixation as result of bending, loosening or breaking of the implants used for fixation. This condition might be attributed to many factors like the use of unsuitable size implant for fixation of fractures in too heavy weight dogs, unstable comminuted fractures, the use of bad quality implant, and osteomyelitis. These findings correlated with those reported by McLaughlin (1999). Implant failure represent $26.6 \%$ from the total number of complications (73/273 cases) and considered as the primary cause for complications of fracture healing 
particularly delayed union, non-union and hypertrophic callus. Because of failure of fixation resulting in mechanical instability at the fracture site and subsequently formation of a non- birding callus.

Delayed union means fracture seems to take a long time to heal while non union means fracture has not healed (Piermaltei \& Flo, 1997). In the present study delayed union and non union with the evidence of pseudoartherosis represented $24.9 \%$ from the total number of complications (68/273). These conditions might be attributed to implant failure, moderate or severe concurrent soft tissue injuries, unstable highly comminuted fractures and osteomyelitis. Similar findings were reported by Piermattei and Gretchen,(1997),Robins,(1998),Stigen,(1999)and Sena et al, (2004).

Mal-union means fracture has healed but with poor alignment that may alter function of that part of the skeleton. It may be associated with angular or rotational deformities and shortening of the limb (Hulse and Hyman, 1993 and Mclaughlin, 1999). In the present study mal-union represented $6.2 \%$ from the total number of complications (17/273) particularly in most cases in which closed reduction technique was used. This condition might be attributed to improper reduction, and improper fixation. These findings were similar to those of Aron \& Dewey, (1992), and Johnson \& DeCamp, (1999).

Hypertrophic callus is considered as irritation non bridging callus observed normally in immature animals and in olders animal in case of infection or instability. In this study, it represented $16 \%$ from the total number of complications (42/273) particularly in young dogs. This condition might be attributed to excessive periosteal stripping (Gadallah et al, 2002). In this respect Permattei and Gretchen, (1997) added that osteomyelitis and mechanical instability at the fracture site may play an important role in the formation of abundant callus. 
In the present study, osteomyelitis represented $6 \%$ from the total number of complications (16/273) particularly in those cases of compound fractures and sometimes in fractures undergone to open reduction incase of internal fixation. This condition might be attributed to contamination of the fracture site due to injury of the skin or during surgical interference. Similar findings were reported by Hararri (1992), Johnson et al (1994), Miller et al (1998) and Stigen (1999).

Regarding the treatment options and preventive measures taken to minimize the incidence of complications among long bone fractures management. The ensuing results were satisfactory in terms of full limb function or slight degree of lameness in case of hypetrophic callus, slight mal-aligment, joint stiffness with mild arthrosis and early stage of muscle atrophy and in some cases of delayed union. However, in case of long standing cases with muscle atrophy (contracture), joint stiffness with severe arthrosis, recurrent implant failures, non-union and osteomyelitis associated with severe bone lysis the results were often disastrous and the only solution for such cases is probably the amputation of the limb or condamination of the animal. Similar findings were reported by McLaughlin (1999) and Dvorak et al, (2000).

\section{CONCLUSIONS}

Complications of long bone fractures constitute a major problem to the veterinary orthopedist. The present study emphasized on the necessity of the age, weight, type of fractured bone, type of fractures, state of fractures, concurrent soft tissue injuries, type of reduction and the method of fixation. If one or more than one of these factors neglected single or multiple complications will take place. 
Treatment options gave satisfactory results in terms of rapid return tofull limb function in some cases of hypertorophic callus, slight malalignment, delayed union, joint stiffness with mild arthrosis and early stage of muscle atrophy. However the ensuing results were fair to poor (moderate or severe lameness) in case of long standing cases of muscle atrophy, joint stiffness with severe arthrosis recurrent implant failure, non union and osteomyelitis.

\section{REFERENCE}

- Aron, D.N., (1998): Practical techniques for fractures In: Bojrab M.J. (ed.): Current techniques in small animal surgery. $4^{\text {th }}$ ed. Philadelphia. 934-941.

- Aron, D.N., Dewey, C.W. (1992): Application and postoperative management of external skeletal fixators. Vet. Clin. North Am. Small Anim. Pract. 22:69-98.

- DeCamp, C.E. (1993): External cooptation in slatter, D. (ed): textbook of small animal surgery. Philadelphia W.B. Saunders, pp 1661-1676.

- Dvorak, M.A., Necos, A. and Zatloukal, J. (2000): Complications of long bone fracture healing in dogs: functional and Radiological criteria for their assessment. Acta Vet, Brno, 69:107-114.

- Egger, E.L. (1998): External skeletal fixation: in current technique in small animal surgery: Bojarb. M.J., Ellison, G.W. and Slocum, B. $4^{\text {th }}$ ed. Pp 1840-1865. 
- Gadallah, S.M., Shamaa, A.A and Farag, K.A (2002): Evaluation of the efficacy of different fixation techniques in canine appendicular skeletal fracture repair: A retrospective study from 1996 to 2002. Vet. Med. J., Giza. Vol. 50, No. 4:911-932.

- Hararri, J. (1992): Complications of external skeletal fixation Vet. Clin., North Am. Small Anim. Pract. Surg. 22: 99-107.

- Hulse, D. and Hyman, B (1993): Fracture biology and biomechanics in Slatter, D, (ed): Textbook of small animal surgery, Philadelphia, W.B. Saunders, pp. 1595-1603.

- Hulse, D.A (1997): Reduction in plate strain by addition of an intra medullary pin. Vet. Surg. 26:451-459.

- Hulse, D.A. and Aron, D.N. (1994): Advances in small animal orthopedics. Compendium 16: 831-832.

- Hulse, D.A.) and Johnson, A.L. (1999): Decision making in facture management. In: Possum, T.W.: Small animal surgery. Mosby-year book, Inc., St. Louis, PP. 730-733.

- Johnson, A.L., and DeCamp, C.E. (1999): External skeletal fixation: Linear fixation Vet. Clin., North Am. Small Anim. Pract. Surg. 29: 1135-1151.

- Johnson, JA., Austin, C., and Breur, G.J. (1994): Incidence of canine appendicular musculoskeletal disorders in 16 veterinary teaching hospitals from 1980 through 1989. Vet. Comp.Orthap.Trauma 7: 56-69.

- McLaughlin, R. (1999): Internal fixation. Vet Clin. Of North. Am. Small Anim. Pract. 29(5): 1097-1115. 
- Miller, C.W., Sumer-smith, G., Sheridan, C., and Pennock, P.W. (1998): Using the unger system to classify 386 long lone fractures in dogs J. Small Anim. Pract. 39:390-393.

- Oakley, R.E. (1999): External coaptation Vet. Clinics of North. America. Small Anim. Pract. 29: 1083-1095.

- Piermattei, D.L., and Gretchen,F.L. (1997): Small animal orthopaedic and fracture repair $3^{\text {rd }}$ Ed. W.B Saunders co. Philadelphia, London. PP. 503-511.

- Prermatei, DL, and Flo, G.L. (1997): Handobook of small animal orthopaedics and fracture repair. Sounders company. USA: 68-95.

- Robins, G. M. (1998): Delayed union. In Brinker, W.O., Olmstead. M.L. Summer-Smith, G. and Prieur, W.D: Manual of internal fixation in Small Animals, $2^{\text {nd }}$ ed. Springer Verlag, Berlin, pp 227-239.

- Senana, N.A.; Gadalha, S.M. and Zabady., M.K. (2004): Studies on some bone disorders in cats. Incidence, radiological assessment and surgical management J. Egypt. Vet. Med. Associ- 64, No. 3: 113-137.

- Shahar, R. (2000): Relative stiffness and stress of type I and type II external fixators: Acrylic versus stainless. Steel connecting bars- a theoretical approach Vet. Surg., 29,59-69.

- Stigen, (1999): Suparcondylar femoral fractures in 159 dogs and cats treated using a normograde intramedullary pinning technique. J. Small Animal Pract. 40: 519- 523. 


\section{دراسات على بعض مضاعفات التئام كسور العظام الطويلة فى الكلاب}

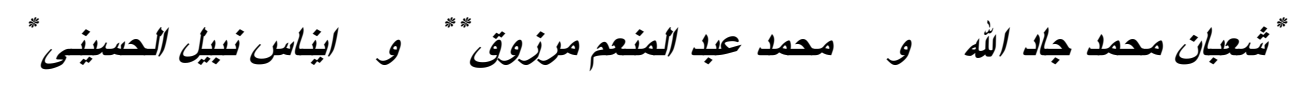
* قسم الجراحة و التخدير وا لأثعة كلية الطب البيطرى - جامعة القاهرة

$$
\text { " * قسم الجراحة كلية الطب البيطرى - جامعة كفر الثيخ }
$$

اشتملت هذه الدراسة على 631 حالة كسر من كسور العظام الطويلة فى الكلاب نم معالجتها فى مستشفى كلية الطب البيطري جامعتي القاهرة و كفر الثيخ من يناير 1998 حتى يناير 2008 فيها 90 حالة عانت من مضاعفات عديدة بمجموع 273 مضاعف تم تصنيف هذه

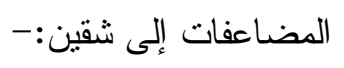

الشق الأول: و اثنتمل على المضاعفات التى تتشأ عن التعامل الغير سليم للكسر وكانت بنسبة (47.6\%) ونجم عنها مضاعفات نثأت عن إطالة عمر التثبيت للكسر (fracture disease) وخاصة التثبيت الخارجي بنوعية مثل ضمور العضلات وتيبس المفاصل.

أما النوع الثاني للتعامل غير السليم للكسر والممثل فى الفنثل فى عملية التثبيت سواء ننتجة الجهل بطرق الثتيث التي أرسلتها رابطة التثبيت الداخلي للكسور (ASIF) أو نتيجة انثاء أو كسر أو تفكك للوسائل المستخدمة في الثنيث.

الشو الثانك: للمضاعفات وهو الذي ينشأ أثناء عملية التئام العظام المكسورة وكانت نسبته 52.4\% و اثشتمل على أنواع كثيرة منها تأخر الالتئام أو نوقفه أو الالتئام الخطأ أو التضخم

$$
\text { المتصلب للكسر أو الالتهاب العظمى النخاعي. }
$$


تمت دراسة نسبة المضاعفات وتحليلها أخذا" فى الاعتبار عمر ووزن الحيوان وكذلك نوع العظام الطويلة المكسورة وحالة الكسر بسيط أم مركب ومدى إصابة الأنسة الرخوة المحيطة بالكسر ونوع الاختز ال وكذلك طريقة أو طرق التثيت. تم متابعة المضاعفات من خلا الفحص الر اديولوجى وتم معالجة بعض هذه المضاعفات.

أظهرت النتائج زيادة نسبة المضاعفات فى عظام الفخذ والعضد وخاصة في الأعمار الصغيرة و المسنة ذات الأوزان الثقيلة. و أظهرت أيضاً النتائج ارتفاع نفس النسبة فى الكسور القديمة (اكثر من أسبوع ) و الكسور المركبة المفتتة المصحوبة بإصابات شديدة فى الآنسة الرخوة، كما أظهرت النتائج ارتقاع نسبة المضاعفات فى التنبيت الخارجي بنوعية .

أظهرت نتائج العلاجات المختلفة للمضاعفات أن الكلاب المكسورة يمكن أن تعود لحالتها الطبيعية من حيث استعمال القائمة المكسورة استعمال كامل وذلك فى حالة التضخم المتصلب للعظم أثناء الالتئام وكذلك المر احل الأولى من تيبس المفاصل وضمور العضلات والحالات المتكررة للتثبيت الغير سليم وحالات الالنئام المتأخر و المتوقف وكذلك في حالة الالتهاب العظمى النخاعي و أكدت هذه الدراسة على أهمية العمر و الوزن ونوع العظام الطويلة الدكسورة ونوع الكسر وحالة الكسر ومدى إصابة الأنسجة الرخوة المحيطة بالكسر وكذلك طريقة أو طرق التثبيت المختلفة وكلها عوامل لا بد أن تأخذ في الاعتبار عند معالجة كسور العظام الطويلة وبخلاف ذلك فان إهمال أحد هذه العو امل يعرض الحيو ان المكسور إلى حدوث أحد من هذه المضاعفات أو أكثر من مضاعف. 